\title{
Characterization and molecular cloning of secreted $\alpha$-amylase with dominant activity from Mon Thong durian (Durio zibethinus Murr. cv. Mon Thong)
}

\author{
Saijai Posoongnoen ${ }^{1}$, Raksmont Ubonbal ${ }^{2}$, Sompong Klaynongsruang ${ }^{3}$, \\ Jureerut Daduang ${ }^{4}$, Sittiruk Roytrakul ${ }^{5}$ and Sakda Daduang ${ }^{6}$
}

\begin{abstract}
The secreted $\alpha$-amylase with dominant activity was purified from the crude extract of Mon Thong durian by steps of ammonium sulphate precipitation and the affinity column chromatography. The purified $\alpha$-amylase (DzAmy1) had a molecular mass of approximately 44 $\mathrm{kDa}$. Its optimum $\mathrm{pH}$ and temperature for activity were 7.0 and $50^{\circ} \mathrm{C}$, respectively. The enzyme was stable from $\mathrm{pH} 6$ to 10 and from 30 to $60^{\circ} \mathrm{C}$. Many metal ions did not affect amylase activity. The gene cloning of DzAmy1 was carried out and it was confirmed that DzAmyl gene consisted of $1,254 \mathrm{bp}$ open reading frame, which encoded 23 amino acids of the signal peptide and 395 amino acids of mature protein with a calculated molecular mass of $43.7 \mathrm{kDa}$. The isoelectric point of the enzyme was 5.78. DzAmy1 was shown to belong to sub-family one of the plant $\alpha$-amylases based on phylogenetic tree analysis. Structural characterization by homology modelling suggested that it consisted of 3 domains with a catalytic triad in domain A. Recombinant DzAmy1 (rDzAmy1) was successfully expressed in Escherichia coli and had hydrolysis activity for starch and ethylidenepNP-G7, which was clearly confirmed the authenticity of DzAmy1 as a functional $\alpha$-amylase.

Index terms: Durio zibethinus Murr. cv. Mon Thong; secreted $\alpha$-amylase; characterization; Escherichia coli.
\end{abstract}

\section{Caracterização e clonagem molecular da $\alpha$-amilase secretada com atividade dominante de Mon Thong durian (Durio zibethinus Murr. cv. Mon Thong)}

Corresponding author: sakdad@kku.ac.th

Received: October 13, 2020 Accepted: March 12, 2021

Copyright: All the contents of this journal, except where otherwise noted, is licensed under a Creative Commons Attribution License.
Resumo -A $\alpha$-amilase secretada, com atividade dominante, foi purificada a partir do extrato bruto de Mon Thong durian através de passos de precipitação utilizando sulfato de amônia e cromatografia de afinidade. A $\alpha$-amilase purificada (DzAmy1) tem massa molecular de aproximadamente 44 $\mathrm{kDa} . \mathrm{O} \mathrm{pH}$ e a temperatura ótimos para a atividade foram 7.0 e $50^{\circ} \mathrm{C}$, respectivamente. A enzima ficou estável no $\mathrm{pH}$ entre 6 e 10 e temperatura entre 30 e $60^{\circ} \mathrm{C}$. Vários íons metais não afetaram a atividade amilásica. A clonagem do gene DzAmy1 foi feita e confirmou que esse gene consiste em 1.254 bp de região codificante, na qual se codificam 23 aminoácidos de peptídeo sinal e 395 aminoácidos da proteína madura com massa molecular calculada de $43.7 \mathrm{kDa}$. O ponto isoelétrico da enzima é de 5.78. A DzAmy1 pertence à subfamília das $\alpha$-amilases de planta, de acordo com dados de filogenia. A caracterização estrutural através de modelagem por homologia sugeriu que a DzAmyl consiste em 3 domínios, com sua tríade catalítica presente no domínio A. A DzAmy1 recombinante (rDzAmy1) foi expressa em Escherichia coli com sucesso e teve sua atividade de hidrólise de amido e etilideno-pNP-G7, as quais claramente confirmaram a autenticidade da DzAmyl como uma $\alpha$-amilase funcional.

Termos para indexação: Durio zibethinus Murr. cv. Mon Thong; $\alpha$-amilase segregada; caracterização; Escherichia coli.

\footnotetext{
${ }^{1}$ Assistant Professor, Faculty of Science and Technology, Nakhon Ratchasima Rajabhat University, Thailand. E-mail: saijai.p@nrru.ac.th ${ }^{\text {(ORCID }}$ 0000-0002-2678-2210)

${ }^{2}$ Doctoral student, Department of Biochemistry, Faculty of Science, Khon Kaen University, Thailand. E-mail: raksmont.u@kkumail.com ${ }^{(0 R c I D}$ 0000-0002-3167-7335)

${ }^{3}$ Professor, Protein and Proteomics Research Center for Commercial and Industrial Purposes, Khon Kaen University, Thailand. E-mail: somkly@kku.ac.th(ORCID 0000-0003-2872-1291)

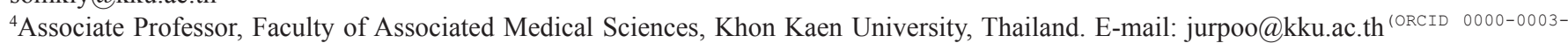
0977-4144)

${ }^{5}$ Researcher, National Science and Technology Development Agency, Thailand. E-mail: sittiruk@biotec.or.th (0RCID 0000-0003-3696-8390) ${ }^{6}$ Professor, Faculty of Pharmaceutical Sciences, Khon Kaen University, Khon Kaen, Thailand. E-mail: sakdad@kku.ac.th (ORCID 0000-0003-2672-7710)
} 


\section{Introduction}

Increased consumption of vegetables and fruit is associate with a lower risk of all causes of mortality, and particularly cardiovascular disease. These are wellknown as excellent sources of polyphenolic compounds and particularly flavonoids. Fruit polyphenols have a wide range of health promoting activities including antioxidant, anti-inflammatory (DREHER, 2018; JOSEPH et al., 2016; RONDANELLI et al., 2018) Durian is the most popular climacteric tropical fruit which is found in the Southeast Asia and has a high energy-potency (A AZIZ, and MHD JALIL, 2019; HARUENKIT et al., 2007). It has creamy texture and a sweet-bitter taste (A AZIZ and MHD JALIL, 2019). In the ripening stage, it was reported that the starch content decreased to $9.44-11.76 \%$ from 40.08 $40.42 \%$ (BAI-NGEW et al., 2014). Ripe durian, which has a unique taste, is very sweet, and sugars content was reported to $48.3 \mathrm{~g}$ per $100 \mathrm{~g}$ of total dry matter (CHAROENKIATKUL et al., 2016). This ripening process results from "high amylase activity" that digests starch during fruit ripening (JAIN et al., 2003). $\alpha$-Amylase (1,4- $\alpha$-D-glucan glucanohydrolase; EC 3.2.1.1) is an important metalloenzyme responsible for catabolising starch, glycogen and disaccharides. $\alpha$-Amylase enzyme is used for many applications in a wide variety of industries such as textile, food, detergent, paper, sugar and pharmaceutical industries (SINDHU et al., 2017). In industrial processes the enzyme was preferably used over chemical catalysts due to the increasing knowledge of the technical and economic advantages together with the need for environmentally safe technology. The thermal stability is desirable feature of the enzyme for its economic viability and long shelf-life in commercial processes. Therefore, intensive studies of structurefunctional relationships of the enzyme are necessary.

Plant alpha-amylases are organized into three subfamilies: secreted $\alpha$-amylase, cytosolic $\alpha$-amylase and plastid $\alpha$-amylase (STANLEY et al., 2005). In Mon Thong durian, only plastid $\alpha$-amylase (DzAmy3) has been reported, which has a predicted molecular mass of $93.7 \mathrm{kDa}$ and an isoelectric point of 5.77. Also recombinant plastid $\alpha$-amylase showed optimum activity at $\mathrm{pH} 8.0$ and $30^{\circ} \mathrm{C}$ (POSOONGNOEN et al., 2015). The present study is a proteomics study of Mon Thong durian. The secreted $\alpha$-amylase (DzAmy 1 ) from Mon Thong durian (Durio zibethinus Murr. cv. Mon Thong) was analysed to determine its biochemical properties and structural characteristics, and the cDNA gene was cloned and expressed as recombinant protein.

\section{Materials and Methods}

\section{SDS-PAGE and 2D-PAGE}

SDS-PAGE was carried out using 13\% gels under reducing conditions (LAEMMLI, 1970). The samples were mixed with $2 \mathrm{X}$ solubilizing buffer ratio 1:1 and heated at $100{ }^{\circ} \mathrm{C}$ for $5 \mathrm{~min}$. Gels were stained with Coomassie brilliant blue R-250 solution. For 2D-PAGE, proteins were focused with IPG strips $(7 \mathrm{~cm})$ at pH 3-11 (Amersham Biosciences, Sweden) using the EttanIPG phor Isoelectric Focusing System (Amersham Biosciences, USA) in gradient mode, yielding 9,250 $\mathrm{Vh}$ for the first dimension. The strip was equilibrated in $1 \%$ DTT and $2.5 \%$ IAA in equilibration buffer (50 $\mathrm{mM}$ Tris- $\mathrm{HCl}(\mathrm{pH} 6.8)$ ) containing $6 \mathrm{M}$ urea, 2\% SDS and $30 \%$ glycerol) prior to the separation of proteins on $13 \%$ polyacrylamide gel. Protein spots were visualized by colloidal Coomassie brilliant blue G-250 solution and analysed by the Image Master 2D Platinum program (Amersham Biosciences, U.S.A).

\section{LC-MS/MS analysis}

The spots of the 2D-PAGE gel were eluted and analysed by liquid chromatography tandem mass spectrometry (LC-MS/MS) according to the previous method (RUNGSA et al., 2016) at the Genome Institute at the National Center for Genetic Engineering and Biotechnology, NSTDA, Thailand. The ion spectra of the peptides were searched on the protein database from SwissProt using MASCOT MS/MS Ion Search program (www.matrixscience.com) with the initial searching parameters; enzyme: trypsin; carbamidomethylation (C): fixed modification; oxidation (HW) and oxidation (M): variable modifications; peptide mass tolerance: $0.5 \mathrm{Da}$; fragment mass tolerance: $0.5 \mathrm{Da}$; a peptide charge state: +1 , $+2,+3$; instrument type: ESI-TRAP; and report top: Auto."

\section{Purification of Native DzAmyl}

All steps of purification of native DzAmy1 were carried out at $4^{\circ} \mathrm{C}$. Ripening durian pulp was homogenized in $50 \mathrm{mM}$ sodium acetate buffer ( $\mathrm{pH} 6.0$ ) including $5 \mathrm{mM}$ $\mathrm{CaCl}_{2}$ and $1 \mathrm{mM} \mathrm{DTT}$. After centrifugation at $12,000 \times \mathrm{g}$ for $30 \mathrm{~min}$, the supernatant was precipitated with $70 \%$ ammonium sulphate solution. The precipitates were recovered by spinning at $10,000 \times \mathrm{g}$ for $30 \mathrm{~min}$, re-dissolved in $50 \mathrm{mM}$ sodium acetate buffer ( $\mathrm{pH}$ 6.0) including $5 \mathrm{mM}$ $\mathrm{CaCl}_{2}$, and dialysed against the same buffer to remove ammonium sulphate. The dialyzed solution was then loaded onto pre-equilibrated epoxy-activated sepharose $6 \mathrm{~B}$ columns ligated with $\beta$-cyclodextrin with $50 \mathrm{mM}$ acetate buffer ( $\mathrm{pH}$ 6.0) including $5 \mathrm{mM} \mathrm{CaCl}_{2}$. The columns were washed with $20 \mathrm{mM}$ acetate buffer ( $\mathrm{pH}$ 
6.0) including $5 \mathrm{mM} \mathrm{CaCl}_{2}$ and $0.5 \mathrm{M} \mathrm{NaCl}$. Elution was carried out with a linear gradient of $\beta$-cyclodextrin from 0 to $15 \mathrm{mg} / \mathrm{mL}$ in the above buffer. The active fractions were pooled and dialysed with $50 \mathrm{mM}$ acetate buffer $(\mathrm{pH}$ 6.0) including $5 \mathrm{mM} \mathrm{CaCl}_{2}$

\section{Amylase activity assay}

For the zymographic method, samples were separated by SDS-PAGE under non-reducing conditions using $13 \%$ polyacrylamide gels containing $0.1 \% \mathrm{w} / \mathrm{v}$ soluble starch. After PAGE gels were washed with $1 \%$ triton X-100 to remove SDS and incubated with $0.2 \%$ soluble starch in $50 \mathrm{mM}$ phosphate buffer $(\mathrm{pH} 7)$ for $6 \mathrm{hr}$ at $37^{\circ} \mathrm{C}$, and stained with activity staining solution $(1 \%$ acetic acid, $10 \mathrm{mM} \mathrm{I}_{2}$ and $14 \mathrm{mM} \mathrm{KI}$ ). The amylase activity was quantified based on the surface area of clear band by using the ImageJ 1.45 image analysis program. For the starch agar plate method, samples $(40 \mu \mathrm{l})$ was added into a hole in a starch agar plate containing $0.5 \%(\mathrm{w} / \mathrm{v})$ soluble starch, $50 \mathrm{mM}$ phosphate buffer $\mathrm{pH} 7.0$ and $1.5 \%(\mathrm{w} / \mathrm{v})$ agar. The plates were incubated overnight in incubator at $37^{\circ} \mathrm{C}$. To visualize the clear zone of amylase activity, the plates were stained with activity staining solution $(1 \%$ acetic acid containing $10 \mathrm{mM} \mathrm{I}_{2}$ and $14 \mathrm{mM} \mathrm{KI}$ ).

For dinitrosalicylate (DNS) method, the reaction mixture consisting $0.25 \mathrm{ml}$ of $1 \%(\mathrm{w} / \mathrm{v})$ soluble starch solution in $0.1 \mathrm{M}$ acetate buffer $(\mathrm{pH} 6.5)$ and $0.25 \mathrm{ml}$ of diluted enzyme was incubated at $37^{\circ} \mathrm{C}$ for $10 \mathrm{~min}$, and the reaction was terminated by addition of $0.5 \mathrm{ml}$ of DNS reagent and heated for $5 \mathrm{~min}$, followed to observe the absorbance at $540 \mathrm{~nm}$ using glucose as standard of reducing sugar (UBONBAL et al., 2017). One unit of enzyme was defined as the amount of enzyme that produce $1 \mu \mathrm{mol}$ of reducing sugar per min. $\alpha$-Type amylase was confirmed using ethylidene-pNP-G7 as substrate according to the manufacturer's protocol (Abnova, Taiwan). One unit was defined as the amount of amylase that cleaves ethylidene- $p \mathrm{NP}-\mathrm{G} 7$ to generate $1.0 \mathrm{nmol}$ of nitrophenol per min at $\mathrm{pH} 7.2,37^{\circ} \mathrm{C}$ (POSOONGNOEN et al., 2015)

\section{Molecular biology}

Total RNA was extracted using Trizol reagent (Invitrogen, USA) following the manual instruction. Gene specific primers (GSP) were designed based on a region of plant $\alpha$-amylase that is conserved among the following species: Hordeum vulgare, Amy2 (AAA32925), Hordeum vulgare, Amy1 (AAA32927), Malus domestica, apple (AAX33232), and Musa acuminata, banana (AAN01149). The cDNA was synthesized by using the RevertAid $^{\mathrm{TM}}$ First Strand cDNA Synthesis Kit (Fermentas, Singapore). For nucleotide sequencing, RT-PCR was used to identify the middle part using primers of DzAmy1F
(5'-ACCCACGTCTGGCTACCTC-3') and DzAmy1R (5'-CCTTATCAGAAGGAAAAGGCC-3'). The full sequences were verified using the rapid amplification of cDNA ends (RACE) system (Invitrogen, USA) following the manual instruction. All PCR fragments were cloned into the pGEM-T Easy vector (Promega, USA) for sequencing. The nucleotide sequences were analyzed by DNA sequencing with the DYEnamic E Dye Terminator Cycle sequencing kit using the MegaBACETM1000 instrument at the Biomolecular Analysis Service Unit (Department of Biochemistry, Faculty of Medicine, Khon Kaen University, Khon Kaen, Thailand). The sequences were confirmed by Automated Sanger Sequencing at First Base Laboratory (Malaysia).

\section{Bioinformatics analysis}

The isoelectric point $(\mathrm{pI})$ and molecular weight $(\mathrm{Mw})$ were computed using the Compute $\mathrm{pI} / \mathrm{Mw}$ tool (http://web.expasy.org/compute_pi/). The signal peptide was predicted using the SignalP version 3.0 server (NIELSEN et al., 1997). The phylogenetic tree was constructed by the neighbour-joining method with 1,000 replicates of bootstrapping in the Molecular Evolutionary Genetics Analysis version 5 program (MEGA5) (SAITOU et al., 1987; TAMURA et al., 2011). The protein sequences of plant $\alpha$-amylases in this study were obtained from the NCBI database (http://www.ncbi.nlm.nih.gov/). The amino acid sequences were compared by using ClustalW2 (http://www.ebi.ac.uk/Tools/msa/clustalw2/) (LARKIN et al., 2007). DzAmy1 structural modelling was performed by using the SWISS-MODEL program (http://swissmodel. expasy.org/) (ARNOLD et al., 2006; KIEFER et al., 2009; SCHWEDE et al., 2003). The $2.8 \AA$ resolution X-ray crystal structure of barley $\alpha$-amylase AMY2 (1BG9) was used as a template (KADZIOLA et al., 1998). The 3D structural models were viewed and superimposed using the PyMOL version 0.99rc6 program (http://www.pymol. org/). The nucleotide sequence of $\alpha$-amylase from Mon Thong durian (DzAmy1) was deposited in the GenBank database (Accession no. KU212896).

\section{Gene cloning and expression}

The gene cloning of DzAmy 1 was carried out using both primers of EDzAmy $1 \mathrm{~F}$ (5'CGCCATATGACGCTCTTATTCCAGGGCTTT-3' with NdeI site) and E D z A m $1 \mathrm{R}$ (5'CCGCTCGAGTTAATTCTTGGCCCATACGGC-3' with XhoI site) with proofreading KOD-plus Taq polymerase (Takara, Japan). The NdeI-XhoI-digested DzAmy1 gene including histidine-tag at $\mathrm{N}$-terminus was ligated into the NdeI-XhoI-digested pCold TF vector (Takara, Japan) using a DNA ligation kit (Takara, Japan). The rDzAmy1was expressed using E. coli BL21(DE3) 
cells (Novagen, Germany) at $37^{\circ} \mathrm{C}$ in $50 \mathrm{~mL}$ LB medium supplemented with $50 \mu \mathrm{g} / \mathrm{mL}$ ampicillin until the $\mathrm{OD}_{600}$ reached $0.4-0.5$. Induction was then carried out with $1 \mathrm{mM}$ IPTG, and cells were grown at $15^{\circ} \mathrm{C}$ for $36 \mathrm{hr}$.

\section{Purification and characterization of rDzAmy1}

rDzAmy1 was purified using Talon-metal affinity resin (Clontech, USA). After clear lysate was applied to the resin, nonspecific proteins were removed from the resin by applying washing buffer $(50 \mathrm{mM}$ phosphate buffer, $500 \mathrm{mM} \mathrm{NaCl}, \mathrm{pH} 7.0$ ) containing $50 \mathrm{mM}$ imidazole. The rDzAmy1 was eluted using stepwise of 100-200 mM imidazole in washing buffer. SDS-PAGE analysis was used to determine the purity of protein. To remove imidazole, the purified enzyme was dialyzed and concentrated with Amicon Ultra-4 Centrifugal Filter Devices (50 kDa MW cutoff; Millipore, Ireland). The purified rDzAmy1 was analysed amylase activity using starch agar plate and specific substrate of ethylidene-pNP-G7. The purified rDzAmy 1 was identified by LC-MS/MS analysis.

\section{Results}

Proteomic pattern and amylase activity of crude extract from Mon Thong durian

Crude extract form Mon Thong durian was subjected to one dimensional (1D) and two-dimensional (2D) separations by SDS-PAGE, based on their molecular weights or/and isoelectric points. The one-dimensional gel showed the proteins having molecular mass ranging 28-97 kDa and the major bands were at 38-55 kDa. The zymographic gel was used to verify amylase activity. The transparent band was appeared at the position of molecular mass approximately $44 \mathrm{kDa}$ (Fig. 1a).

The 2D gel presented the proteome of the extract of the durian and revealed approximately 40 major protein spots (Figure $1 \mathrm{~b}$ and Table 1) with isoelectric points (pI) mostly ranging from 4.54 to 8.01 and mass ranging from 27 to $81 \mathrm{kDa}$. A total of 27 protein spots were massfingerprinted and roughly grouped into 9 categories (Figure 1c): carbohydrate metabolism (19.07\%), protein metabolism (34.74\%), lipid metabolism (1.47\%), stress response $(5.98 \%)$, antioxidant enzymes $(5.71 \%)$, cell wall hydrolases (3.51\%), secondary metabolism proteins $(1.50 \%)$, ripening process enzymes $(0.96 \%)$ and others $(27.06 \%)$. According to these peptide mass fingerprints, any protein did not match to amylase, indicating its low expression.

\section{Purification of native DzAmyl}

To purify DzAmy1, the durian crude extract was precipitated by addition of ammonium sulphate, which was able to remove starch, sugar and some unexpected protein. The DzAmyl can be purified in one step by epoxy-activated separose 6B affinity chromatography. The amylase activity fraction was showed in the minor peak of the elute fraction No. 70-90 (Figure 2a). The purified DzAmy1 revealed higher than 300 fold with a specific activity about $216 \mathrm{U} / \mathrm{mg}$ (Table 2). SDS-PAGE of the fraction showed a faint but single band of purified DzAmy1 having molecular mass of approximately 44 $\mathrm{kDa}$, which was corresponded to the transparent band of the zymographic gel examined for amylase activity (Figure 2b).

\section{Enzymatic characterization of native DzAmyl}

The native DzAmy1 showed $\alpha$-amylase activity between $\mathrm{pH}$ 4-10 and the maximum activity at $\mathrm{pH} 7$ (Fig 2c). DzAmy1 was stable in the range of $\mathrm{pH} 6-10$, but activity was drastically diminished under acidic conditions of $\mathrm{pH} 4$ and 5 (Figure 2d). The enzyme exhibited high activity (more than $80 \%$ of original activity) in a broad range of temperatures $\left(30-80^{\circ} \mathrm{C}\right)$, showing the optimal temperature at $50^{\circ} \mathrm{C}$ (Figure 2e). Interestingly, the enzyme was highly active even at $90^{\circ} \mathrm{C}$ with $61 \%$ of relative activity. It was stable at $30-60^{\circ} \mathrm{C}$ and retained more than $40 \%$ of its original activity (Figure $2 \mathrm{f}$ ). The metal ions $\left(\mathrm{Ca}^{2+}, \mathrm{Mn}^{2+}, \mathrm{Zn}^{2+}, \mathrm{Co}^{2+}, \mathrm{Na}^{+}\right.$and $\mathrm{K}^{+}$ions) did not affect enzyme activity relative to the control (Figure $2 \mathrm{~g}$ ). However, the amylase activity was completely abolished by a chelating agent, EDTA, indicating that divalent ions may be required for enzyme activity.

\section{Sequence analysis of DzAmyl}

Next, the gene cloning of DzAmy1 was attempted according to procedure described in "Materials and Methods". The results of sequence analysis are described as the following. The 1736 bp cDNA of DzAmy 1 consist of 30 bp 5'untranslated region (5'UTR), $158 \mathrm{bp} \mathrm{3'TR} \mathrm{and} 1254 \mathrm{bp}$ open reading frame (ORF) (Figure 3, GenBank accession no. KU212896). The 1,254 bp of ORF was deduced to be 418 amino acid (aa), containing a predicted 23 aa putative signal peptide with cleavage site between Pro23 and Thr24. The remaining 395 aa corresponds to the mature protein. The molecular mass and $\mathrm{pI}$ of the mature protein were predicted to be $43.7 \mathrm{kDa}$ and 5.78, respectively. 
Table 1. The proteins of the durian fruit identified by 2D-PAGE and LC-MS/MS.

\begin{tabular}{|c|c|c|c|}
\hline Protein annotation & Spot no. & MW (kDa)/pI theor. & MW (kDa)/pI exp. \\
\hline \multicolumn{4}{|l|}{ Carbohydrate metabolism } \\
\hline Enolase & 13 & $48.30 / 5.42$ & $58 / 6.47$ \\
\hline Phosphoglycerate kinase & 23 & $42.15 / 5.64$ & $43 / 6.73$ \\
\hline Fructose-bisphosphate aldolase & 24,25 & $39.24 / 6.96$ & $41-43 / 7.18-7.46$ \\
\hline Oxidoreductase & 36 & $49.86 / 8.30$ & $33 / 5.74$ \\
\hline Granule-bound starch synthase & 31,32 & $27.84 / 5.38$ & $39 / 7.59-8.01$ \\
\hline \multicolumn{4}{|l|}{ Protein metabolism } \\
\hline Aminotransferase & $16,17,18,19,20,21$ & $42.62 / 6.54$ & $49-54 . / 6.66-7.58$ \\
\hline Elongation factor $\mathrm{G}$ & 8 & $46.48 / 5.75$ & $65 / 6.21$ \\
\hline Leucine aminopeptidase & 10 & $58.60 / 5.75$ & $60 / 6.45$ \\
\hline RNA polymerase $\mathrm{C}$ & 11,12 & $18.12 / 8.64$ & $51 / 5.82$ \\
\hline \multicolumn{4}{|l|}{ Secondary metabolism } \\
\hline Flavonoid glycosyltransferase & 28 & $50.51 / 5.84$ & $39 / 7.04$ \\
\hline \multicolumn{4}{|l|}{ Lipid metabolism } \\
\hline S-malonyl transferase & 33 & $37.10 / 7.08$ & $37 / 6.02$ \\
\hline \multicolumn{4}{|l|}{ Antioxidant enzyme } \\
\hline Glutathione reductase & 15 & $54.20 / 6.59$ & $58 / 7.28$ \\
\hline Isoflavone reductase homolog 1 & 34 & $33.98 / 5.75$ & $37 / 7.32$ \\
\hline \multicolumn{4}{|l|}{ Ripening process enzyme } \\
\hline Ethylene-responsive protein & 35 & $20.79 / 7.68$ & $36 / 6.99$ \\
\hline \multicolumn{4}{|l|}{ Cell wall hydrolase } \\
\hline Glycosyl hydrolase family 10 & 5 & $63.05 / 6.12$ & $62 / 4.54$ \\
\hline Cellulase & 38 & $57.36 / 8.14$ & $30 / 7.72$ \\
\hline \multicolumn{4}{|l|}{ Stress response } \\
\hline Heat shock protein Hsp 70 & 1 & $69.2 / 6.38$ & $81 / 5.72$ \\
\hline $60-\mathrm{kDa}$ chaperonin & 3 & $19.84 / 4.75$ & $69 / 6.20$ \\
\hline \multicolumn{4}{|c|}{ Other (Not identified) Spot no. 2, 4, 6, 7, 9, 14, 22, 26, 27, 29, 30, 37, 39, 40} \\
\hline
\end{tabular}

Table 2. Purification of $\alpha$-amylase from Mon Thong durian (Durio zibethinus Murr. cv. Mon Thong).

\begin{tabular}{|c|c|c|c|c|c|}
\hline Purification steps & $\begin{array}{l}\text { Total activity } \\
\text { (U) }\end{array}$ & $\begin{array}{l}\text { Total protein } \\
(\mathrm{mg})\end{array}$ & $\begin{array}{l}\text { Specific activity } \\
(\mathrm{U} / \mathrm{mg})\end{array}$ & $\begin{array}{l}\text { Purification } \\
\text { (fold) }\end{array}$ & $\begin{array}{c}\text { Yield } \\
(\%)\end{array}$ \\
\hline Crude extract & 271.00 & 394.00 & 0.69 & 1 & 100.00 \\
\hline $\begin{array}{l}70 \% \text { Ammonium sulphate } \\
\text { precipitation }\end{array}$ & 46.80 & 33.60 & 1.39 & 2.02 & 17.27 \\
\hline $\begin{array}{l}\text { Epoxy activated sepharose } \\
\text { 6B Affinity chromatography }\end{array}$ & 2.81 & 0.01 & 216.00 & 313.04 & 1.04 \\
\hline
\end{tabular}



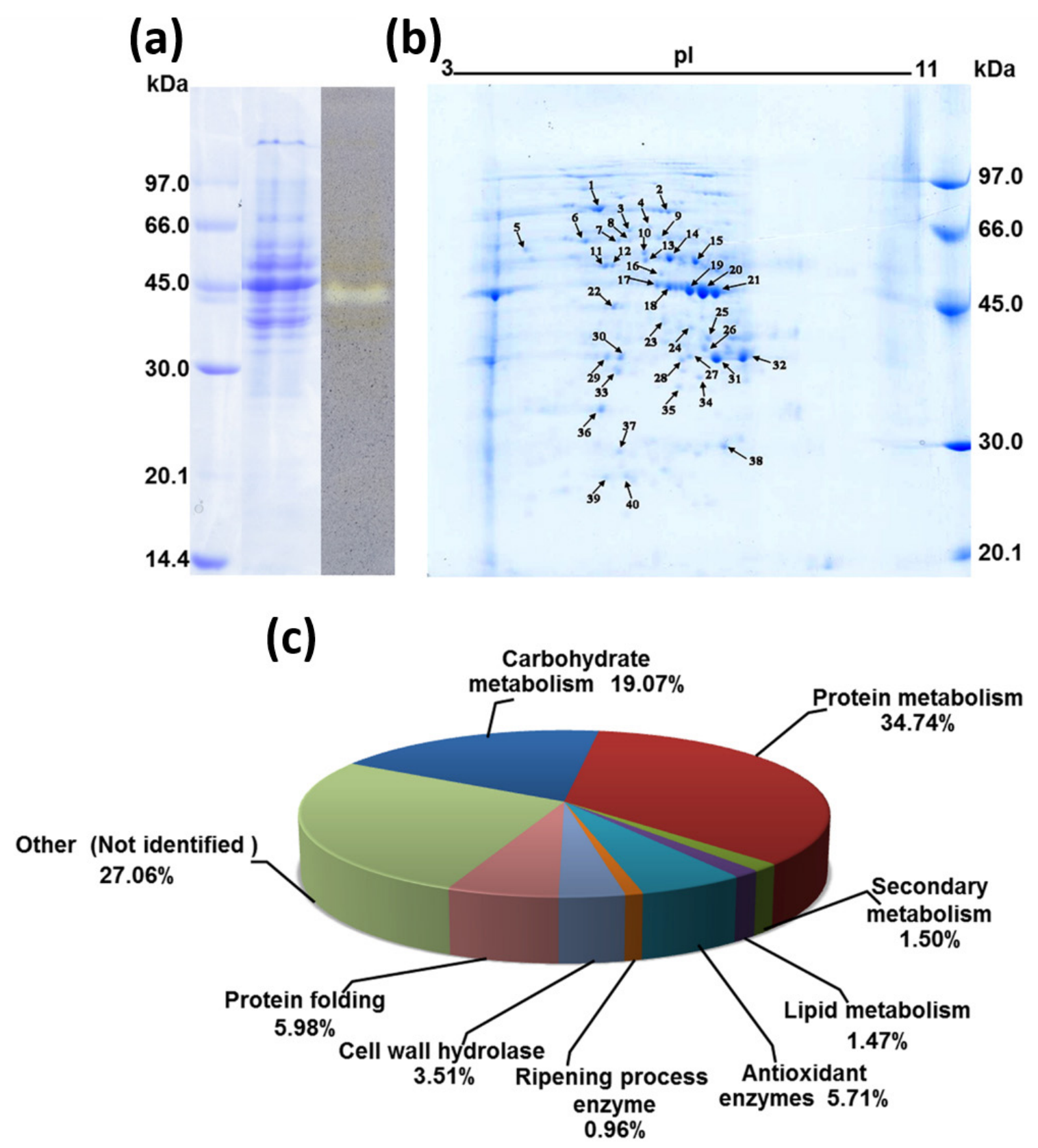

Figure 1. Proteomic pattern of Mon Thong durian pulp and amylase activity assay. (a) Zymographic analysis on a $13 \%$ acrylamide gel containing $0.1 \%$ soluble starch. (b) Representative 2D-PAGE profile of proteins in Mon Thong durian (IPG strip pH 3-11 size $7 \mathrm{~cm}$ ). The major protein spots are numbered. (c) Functional classification and the correspondence percentage of each class are indicated. 
(a)

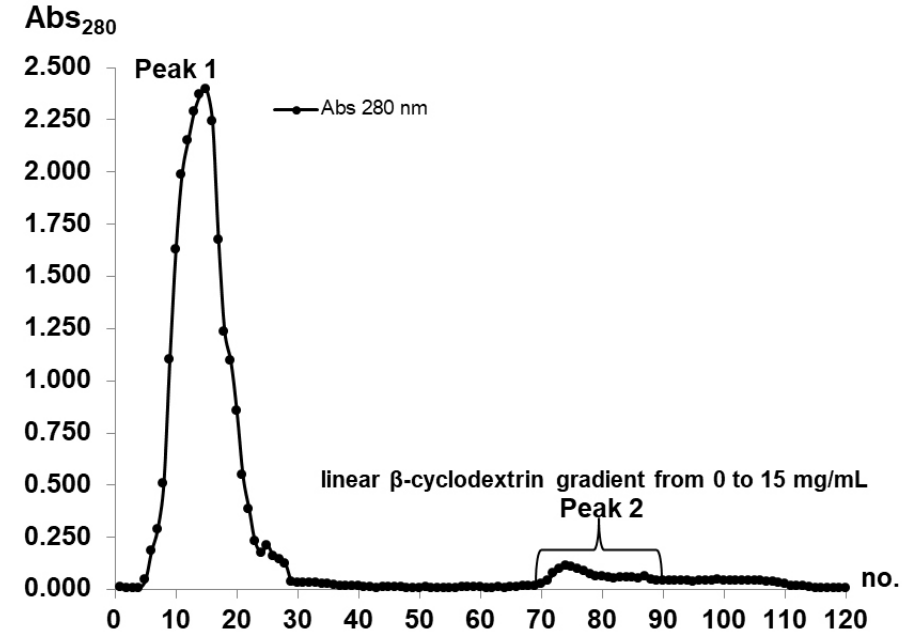

(b)

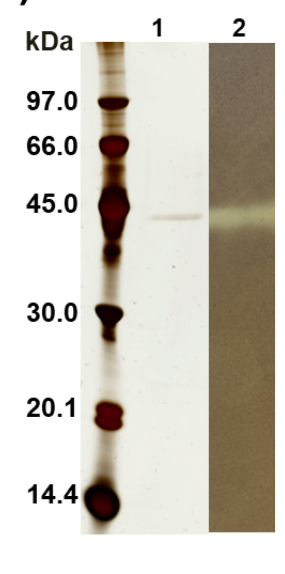

(c)

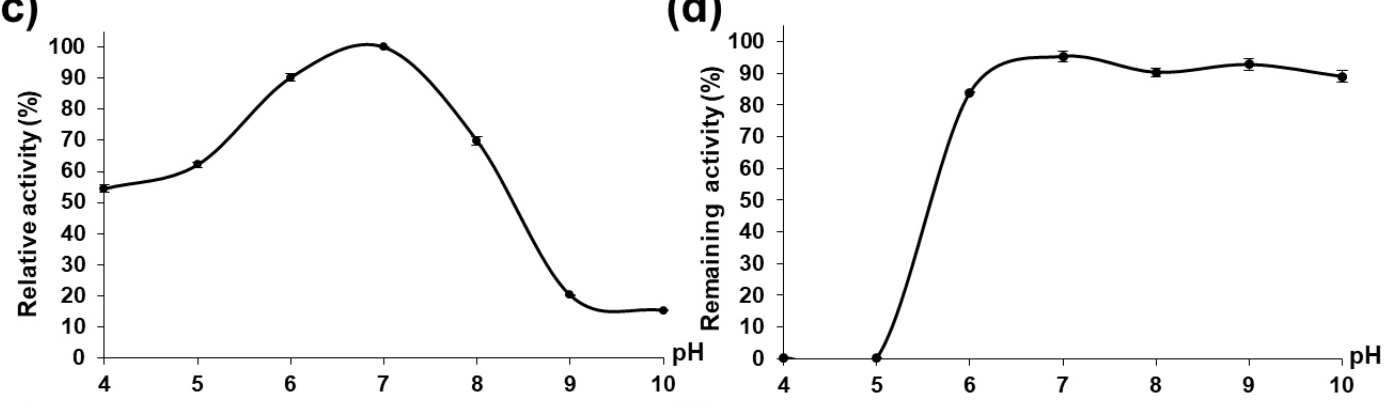

(e)

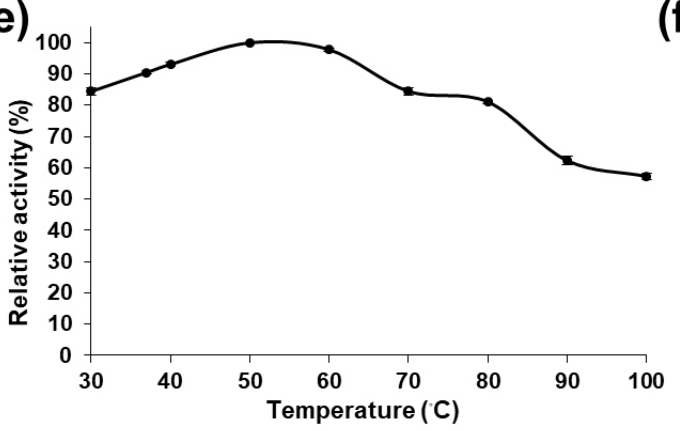

(f)

(d)

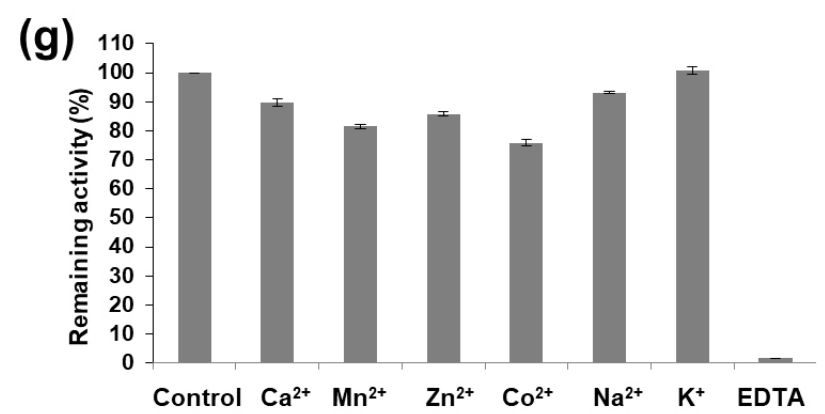

Figure 2. Purification and characterization of DzAmy1. (a) Elution profile of purification using epoxy-activated Sepharose 6B linked with $\beta$-cyclodextrin for affinity chromatography. (b) SDS-PAGE analysis (lane 1) and amylase activity assay using the zymographic method (lane 2) for purified amylase. (c) Effect of pH on amylase activity. Amylase activity was analysed at $\mathrm{pH} 4$ to 10 at $37^{\circ} \mathrm{C}$. The $\mathrm{pH}$ conditions were adjusted using the following $50 \mathrm{mM}$ buffers: sodium acetate $\mathrm{pH} 4-5$, potassium phosphate $\mathrm{pH} 6-7$, Tris- $\mathrm{HCl} \mathrm{pH} 8-10$. The maximum activity at $\mathrm{pH} 7.0$ was taken as $100 \%$ activity. (d) The effect of $\mathrm{pH}$ on amylase stability was determined by measuring the residual activity after incubating the purified amylase in various buffers at $\mathrm{pH} 4-10$ for $30 \mathrm{~min}$ at $37^{\circ} \mathrm{C}$. The activity of the enzyme before incubation was considered to be $100 \%$ activity. (e) The effect of temperature on amylase activity was determined from 30 to $100^{\circ} \mathrm{C}$ at $\mathrm{pH} 7.0$. The maximum activity at $50^{\circ} \mathrm{C}$ was taken as $100 \%$ activity. (f) The effect of temperature on amylase stability was tested by measuring the residual activity after exposure of purified amylase from 30 to $100^{\circ} \mathrm{C}$ at $\mathrm{pH} 7$ for $30 \mathrm{~min}$. (g) The effects of metal ions and EDTA on amylase activity were determined by pre-incubating the purified amylase with $5 \mathrm{mM}$ of each metal ions and EDTA for $30 \mathrm{~min}$. The original activity before pre-incubation was taken as $100 \%$ activity. 
aagaggctaagagaccaagtcacctatagaATGATTTCTCTCACATCACTTTGCTTCCT T

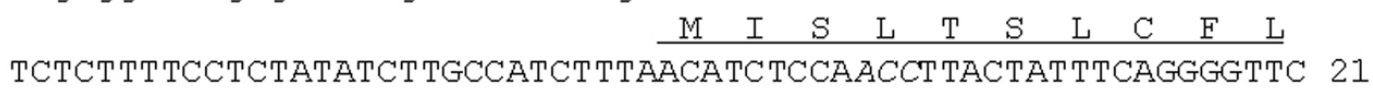
$\begin{array}{lllllllllllllllllllllllll}\mathrm{S} & \mathrm{L} & \mathrm{F} & \mathrm{L} & \mathrm{Y} & \mathrm{I} & \mathrm{L} & \mathrm{P} & \mathrm{S} & \mathrm{L} & \mathrm{T} & \mathrm{S} & \mathrm{P} & \mathrm{T} & \mathrm{L} & \mathrm{L} & \mathrm{F} & \mathrm{Q} & \mathrm{G} & \mathrm{F} & 7\end{array}$ AACTGGGAGTCATGTAACAAGGCAGGAGGATGGTATAAC TCTCTCAAGAAT TCCATCCCT 81 $\begin{array}{lllllllllllllllllllll}\mathrm{N} & W & \mathrm{E} & \mathrm{S} & \mathrm{C} & \mathrm{N} & \mathrm{K} & \mathrm{A} & \mathrm{G} & \mathrm{G} & \mathrm{W} & \mathrm{Y} & \mathrm{N} & \mathrm{S} & \mathrm{L} & \mathrm{K} & \mathrm{N} & \mathrm{S} & \mathrm{I} & \mathrm{P} & 27\end{array}$ GATATTGCTAATGCTGGAGTTACTCATGTCTGGCTTCCTCCACCCTCCCAGTCAGTTGGA 141 $\begin{array}{lllllllllllllllllllll}D & I & A & N & A & G & V & T & H & V & W & L & P & P & P & S & Q & S & V & G & 47\end{array}$ CCCCAAGGATATCTCCCAGGAAGACTTTATGATCTCGATGCATCAAAGTATGGATCTCAG 201 $\begin{array}{lllllllllllllllllllll}P & Q & G & Y & L & P & G & R & L & Y & D & L & D & A & S & K & Y & G & S & Q & 67\end{array}$ GCTGGATTGAAGTCGCTAATTGAAGCTTTCCATCAGAAGGGAATCAAATGTTTAGCTGAC 261 $\begin{array}{lllllllllllllllllllll}A & G & L & K & S & L & I & E & A & F & H & Q & K & G & I & K & C & L & A & D & 87\end{array}$ ATAGTAATAAACCATAGAACAGCCGAGAGGAAAGATGGAAGAGGAATATATTGCATTTTT 321 $\begin{array}{lllllllllllllllllllll}I & V & I & N & H & R & T & A & E & R & K & D & G & R & G & I & Y & C & I & F & 107\end{array}$ GAAGGTGGAAC TCCAGATGATCGTTTGGATTGGGGGCCATCATTCATTTGTGGAAATGAT 381 $\begin{array}{lllllllllllllllllllll}E & G & G & T & P & D & D & R & L & D & W & G & P & S & F & I & C & G & N & D & 127\end{array}$ AGGGAGTAT TCGGATGGTACAGGCAATCCTGACACTGGACTGGATTATCAACCTGCTCCT 441 $\begin{array}{lllllllllllllllllllll}R & E & Y & S & D & G & T & G & N & P & D & T & G & L & D & Y & Q & P & A & P & 147\end{array}$ GACATTGATCATCTCAATCCAAGGGTGCAAAATGAGTTATCTGATTGGATGAATTGGTTA 501 $\begin{array}{lllllllllllllllllllll}\mathrm{D} & \mathrm{I} & \mathrm{D} & \mathrm{H} & \mathrm{L} & \mathrm{N} & \mathrm{P} & \mathrm{R} & \mathrm{V} & \mathrm{Q} & \mathrm{N} & \mathrm{E} & \mathrm{L} & \mathrm{S} & \mathrm{D} & \mathrm{W} & \mathrm{M} & \mathrm{N} & \mathrm{W} & \mathrm{L} & 167\end{array}$ AAGACTGAAAT TGGTTT TGATGGATGGAGATTTGATTTTTAAGAGGTTATGCCCCAAGC 561 $\begin{array}{lllllllllllllllllllll}\mathrm{K} & \mathrm{T} & \mathrm{E} & \mathrm{I} & \mathrm{G} & \mathrm{F} & \mathrm{D} & \mathrm{G} & \mathrm{W} & \mathrm{R} & \mathrm{F} & \mathrm{D} & \mathrm{F} & \mathrm{V} & \mathrm{R} & \mathrm{G} & \mathrm{Y} & \mathrm{A} & \mathrm{P} & \mathrm{S} & 187\end{array}$ ATTACCAAAATATATATGGAACGAACTTCACCAGATTTTGCAGTTGGGGAGAAGTGGGAA 621 $\begin{array}{lllllllllllllllllllll}I & \mathrm{~T} & \mathrm{~K} & \mathrm{I} & \mathrm{Y} & \mathrm{M} & \mathrm{E} & \mathrm{R} & \mathrm{T} & \mathrm{S} & \mathrm{P} & \mathrm{D} & \mathrm{F} & \mathrm{A} & \mathrm{V} & \mathrm{G} & \boldsymbol{E} & \mathrm{K} & \mathrm{W} & \mathrm{E} & 207\end{array}$ GATTTTCCCTGGGGCAGAATCAAGATTCGCATCGTGGAGCTCTGAAAGAT TGGGTTCGA 681 $\begin{array}{lllllllllllllllllllll}D & F & S & L & G & Q & N & Q & D & S & H & R & G & A & L & K & D & W & V & R & 227\end{array}$ GCTGCTGGTGGGGTTGTCAAAGCATTTGATTTCACCACAAAAGGGGTTCTCAATGCTGCA 741 $\begin{array}{lllllllllllllllllllll}A & A & G & G & V & V & K & A & F & D & F & T & T & K & G & V & L & N & A & A & 247\end{array}$ GTACAAGGGGAGTTGTGGCGGCTGAAGGATTCCAATGGGAAACCTCCTGGAATGATTGGA 801 $\begin{array}{lllllllllllllllllllllllllll}V & Q & G & E & L & W & R & L & K & D & S & N & G & K & P & P & G & M & I & G & 267\end{array}$ CTTTTGCCTCGAAGTGCTGTTACTTTTATTGATAATCACGATACAGGTTCTACTCAAAGG 861

$\begin{array}{lllllllllllllllllllll}\mathrm{L} & \mathrm{L} & \mathrm{P} & \mathrm{R} & \mathrm{S} & \mathrm{A} & \mathrm{V} & \mathrm{T} & \mathrm{F} & \mathrm{I} & \mathrm{D} & \mathrm{N} & \mathrm{H} & \mathrm{D} & \mathrm{T} & \mathrm{G} & \mathrm{S} & \mathrm{T} & \mathrm{Q} & \mathrm{R} & 287\end{array}$ CTTTGGCCTTCCCTTCTGATAAAGTCATGCAGGGATATGCTTATATTCTCACCCATCCT 921 $\begin{array}{lllllllllllllllllllll}\mathrm{L} & W & \mathrm{P} & \mathrm{F} & \mathrm{P} & \mathrm{S} & \mathrm{D} & \mathrm{K} & \mathrm{V} & \mathrm{M} & \mathrm{Q} & \mathrm{G} & \mathrm{Y} & \mathrm{A} & \mathrm{Y} & \mathrm{I} & \mathrm{L} & \mathrm{T} & \mathrm{H} & \mathrm{P} & 307\end{array}$ GGCACCCCATCAATATTCTATGATCACTTTGTTGATTGGGGCTTGAAGGATGAGATTACT 981 $\begin{array}{lllllllllllllllllllll}G & T & P & S & I & F & Y & D & H & F & V & D & W & G & L & K & D & E & I & T & 327\end{array}$ AAATTGGAACAATAAGGAGCAAGAATGGAATTAGTGCCACGAGCACACTTAATATTCTA 1, 041 $\begin{array}{lllllllllllllllllllll}K & \mathrm{~L} & \mathrm{~A} & \mathrm{~T} & \mathrm{I} & \mathrm{R} & \mathrm{S} & \mathrm{K} & \mathrm{N} & \mathrm{G} & \mathrm{I} & \mathrm{S} & \mathrm{A} & \mathrm{T} & \mathrm{S} & \mathrm{T} & \mathrm{L} & \mathrm{N} & \mathrm{I} & \mathrm{L} & 347\end{array}$ GCATCAGAT TCTGATCTCTATGTTGCTGCAATTGATGGGAAAATCATTATGAAGATTGGC 1, 101 $\begin{array}{lllllllllllllllllllll}A & S & D & S & D & L & Y & V & A & A & I & D & G & K & I & I & M & K & I & G & 367\end{array}$ CCAAAGT TGGATCTTGGGAACCTTGTACCTTCAAATTACCAGCTTGTTACCTCAGGGAAA 1, 161 $\begin{array}{lllllllllllllllllllll}\mathrm{P} & \mathrm{K} & \mathrm{L} & \mathrm{D} & \mathrm{L} & \mathrm{G} & \mathrm{N} & \mathrm{L} & \mathrm{V} & \mathrm{P} & \mathrm{S} & \mathrm{N} & \mathrm{Y} & \mathrm{Q} & \mathrm{L} & \mathrm{V} & \mathrm{T} & \mathrm{S} & \mathrm{G} & \mathrm{K} & 387\end{array}$ GACTACGCGGTATGGGCAAAGAATTGAgatagaaatcat tgttccaacggaaatgtcgCC 1, 185 $\begin{array}{llllllllll}\mathrm{D} & \mathrm{Y} & \mathrm{A} & \mathrm{V} & \mathrm{W} & \mathrm{A} & \mathrm{K} & \mathrm{N} & * & 395\end{array}$ aaaagatattctaaagactattttggctaaatttatcgtaacttctgtatgaatattag tgaaataaataaattctaatactagtaattt taat taaaaaaaaaaaaaaaaaaaaaaa aaaaa

Figure 3. The complete nucleotide sequences and deduced amino acid sequences of DzAmy1 (GenBank accession no. KU212896). The numbers correspond to the mature DzAmy1 sequence. The catalytic triad (Asp179, Glu204, and Asp281) is marked with bold and italic letters. The start of the mature protein and stop (TAA) codon are represented with italic letters and an asterisk, respectively. The putative signal peptide is indicated by underlined letters. 


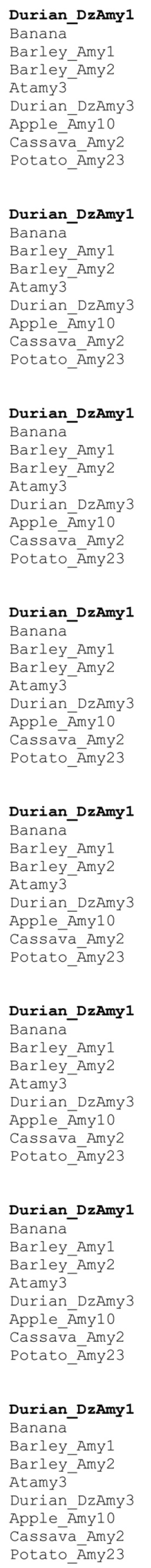

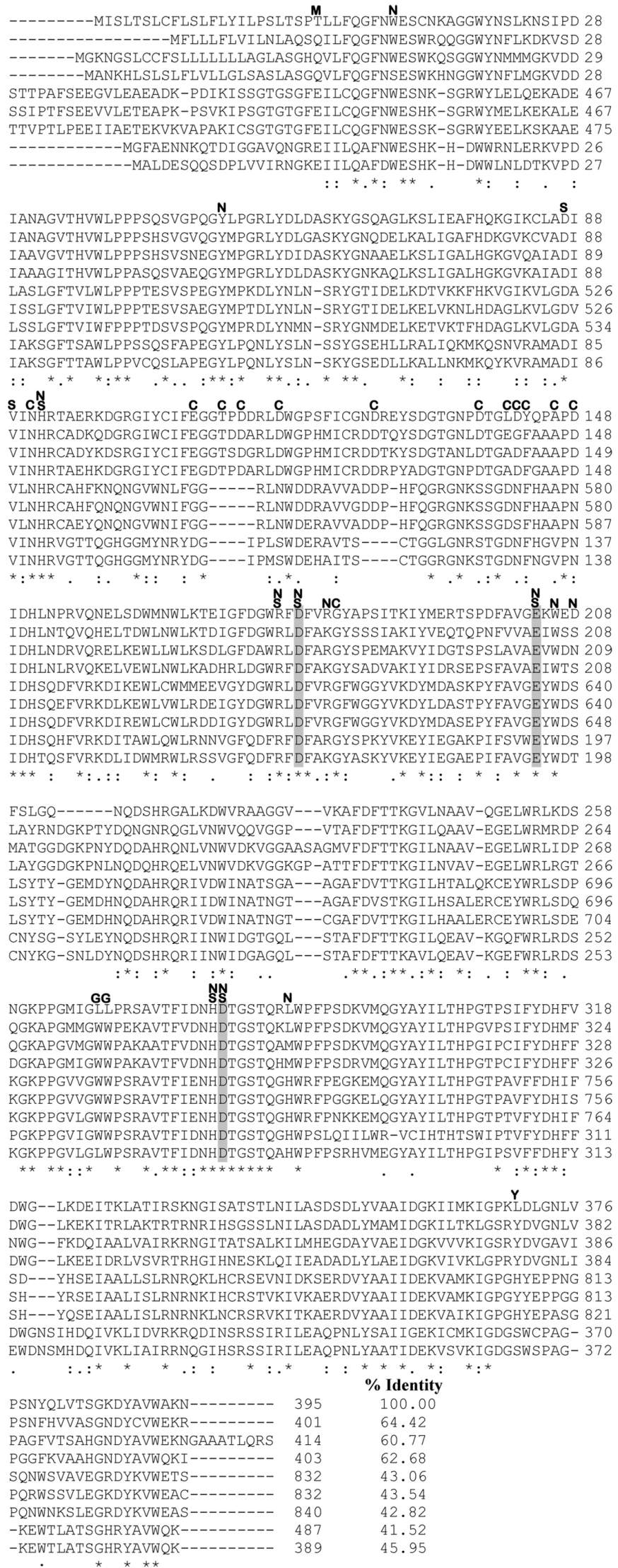

Figure 4. The amino acid sequence alignment of DzAmy1 and other plant $\alpha$-amylases. Residues labelled with $\mathbf{M}$ indicate the start (Gln25) of the mature protein at the N-terminus of barley Amy2 (KADZIOLA et al., 1994). Residues conserved in starch hydrolase are in marked with $\mathbf{S}$. Residues labelled in close proximity to three calcium ions in barley $\alpha$-amylase (KADZIOLA et al., 1994) are marked with $\mathbf{C}$. Residues labelled with $\mathbf{N}$ are those that have hydrogen bond interactions with the acarbose inhibitor and are near the active site in barley $\alpha$-amylase (KADZIOLA et al., 1998). Residues labelled with $\mathbf{G}$ and $\mathbf{Y}$ are in the starch granule binding site (SOGAARD et al., 1993) and sugar binding site (ROBERT et al., 2003) in barley $\alpha$-amylase. The catalytic residues (Asp, Glu and Asp) are highlighted with bold letters and grey shading. 
Amino acid sequence alignment and evolutionary tree analysis of DzAmy1

The catalytic triad of the DzAmyl active site is highly conserved in other plants (Figure 4). Asp179, Glu204, and Asp281 correspond to Asp180, Glu205, Asp291 of barley Amy1 (ROBERT et al., 2003) and Asp179, Glu204, Asp289 of barley Amy2 (KADZIOLA et al., 1994), respectively (Figure 4). Almost all of the residues near the active site that are involved in hydrogen bonding with the substrate analogue of acarbose were also present in DzAmy1. The calcium-binding residues of the enzyme are also highly conserved, even with only two substitutions. In the starch granule binding site, two consecutive tryptophans are replaced with leucines (L). Phylogenetic tree analysis revealed that DzAmy1 was clustered in family one which includes $\alpha$-amylases from cereal grains (rice, maize, bean, wheat and barley), fruits (banana and apple Amy2) and potato, and had the predicted secretory signal peptides (Figure 5). DzAmyl was closely related to potato, French bean and black gram, sharing $73.90 \%, 75.36 \%$ and $77.27 \%$ identity, respectively.

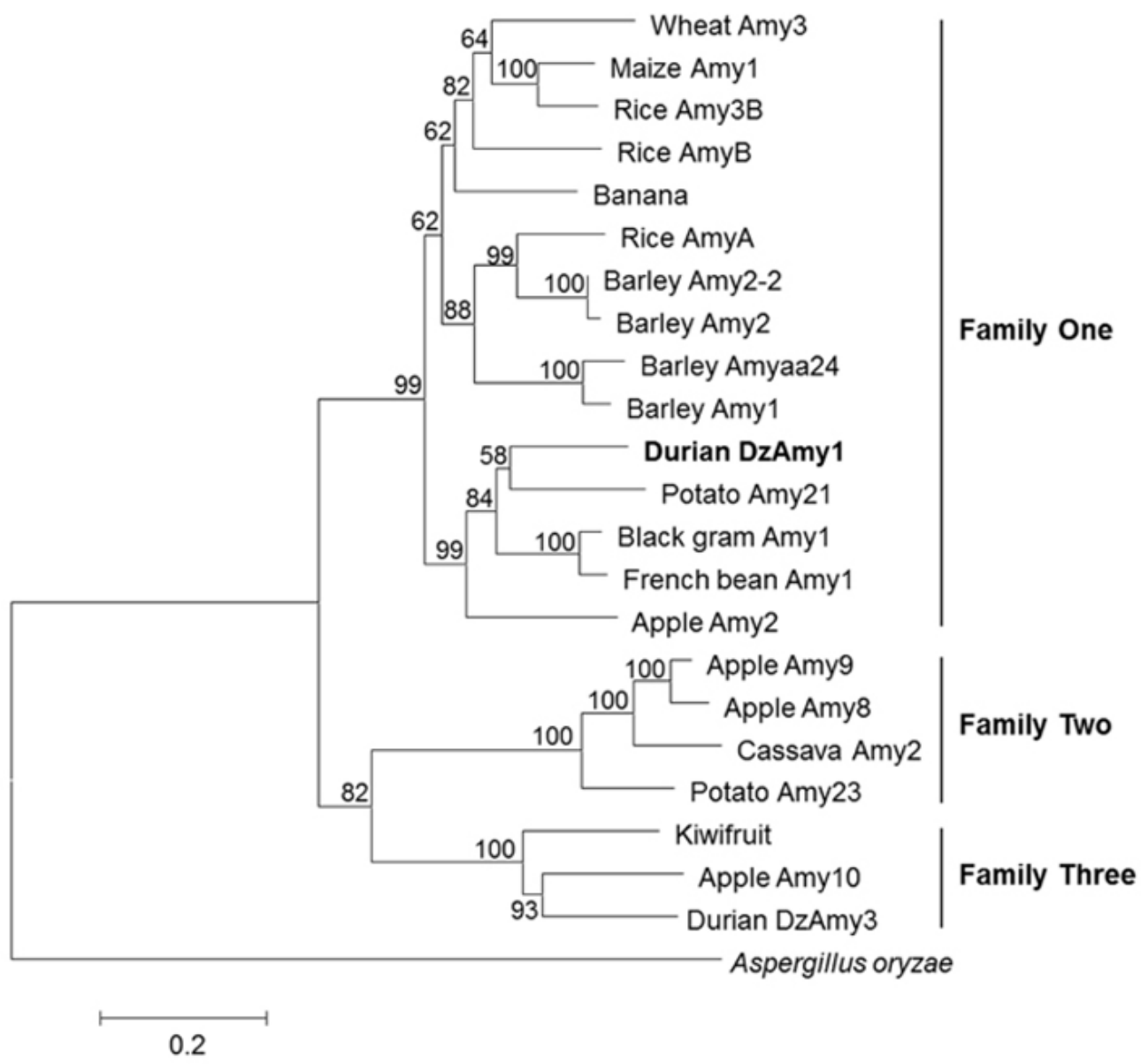

Figure 5. Evolutionary tree analysis and tertiary structure of DzAmy1 by homology modelling. The plant $\alpha$-amylase phylogenetic tree analysis. The tree was constructed by using the MEGA5 program (TAMURA et al., 2011) with the neighbour-joining method (SAITOU et al., 1987). The bootstrap values were derived from 1,000 bootstrap replicates, and the values are shown as percentages. The plant $\alpha$-amylases used in this study are as follows: Durio zibethinus Murr. cv. Mon Thong, Durian DzAmy1 (KU212896), Durian DzAmy3 (KP164993); Malus domestica, Apple Amy10 (AAX33231), Apple Amy8 (AAF63239), Apple Amy9 (AAX33234), Apple Amy2 (AAX33232); Actinidia chinensis, Kiwifruit (AAX33233); Musa acuminata, Banana (AAN01149); Manihot esculenta, Cassava Amy2 (AAY85174); Hordeum vulgare, Barley Amy2 (AAA32925), Barley Amy1 (AAA32927), Barley Amy2-2 (AAA98790), Barley Amyaa24 (CAA72143); Oryza sativa, Rice AmyA (AAA33885), Rice Amy3B (AAA33897), Rice AmyB (AAA33886); Phaseolus vulgaris, French bean Amy1 (BAA33879); Solanum tuberosum, Potato Amy 21 (AAA91883), Potato Amy23 (AAA91884), Triticum aestivum, Wheat Amy3 (AAA34259), Zea mays, Maize Amy1 (AAA50161); Vigna mungo, Black gram Amy1 (CAA37217); Aspergillus oryzae (AAA32708) . 
Supposed tertiary structure of DzAmyl by homology modelling

The $65 \%$ identity of amino acid sequence between DzAmy1 and barley $\alpha$-amylase AMY2 (1BG9) striked us an idea to compare with the X-ray crystal structure of barley AMY2 (KADZIOLA et al., 1998). 3D structure modelling of DzAmy1 was sufficiently accurate to elucidate its characterization. DzAmy1 modelling suggested to consist

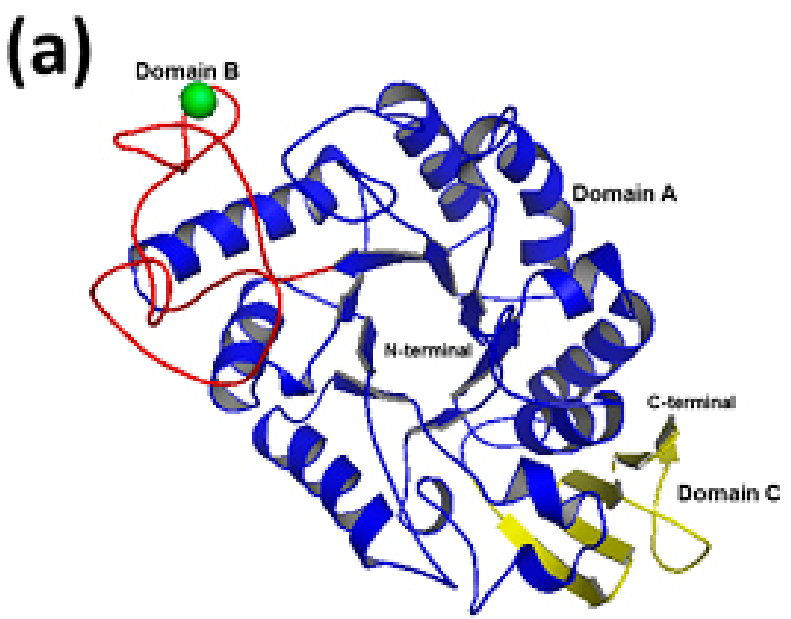

of the $\mathrm{A}, \mathrm{B}$ and $\mathrm{C}$ domains in single polypeptide chain (Figure 6a). Superimposition revealed that the crystal structures of AMY2 (1BG9, complexed with acarbose) and DzAmy 1 model were highly similar (Figure 6b). The catalytic residues that are important for general acid/base hydrolysis in barley AMY2 (Asp179, Glu204 and Asp289) are identical to those of DzAmy1 (Asp179, Glu204 and Asp281) according to the amino acid sequence alignment.

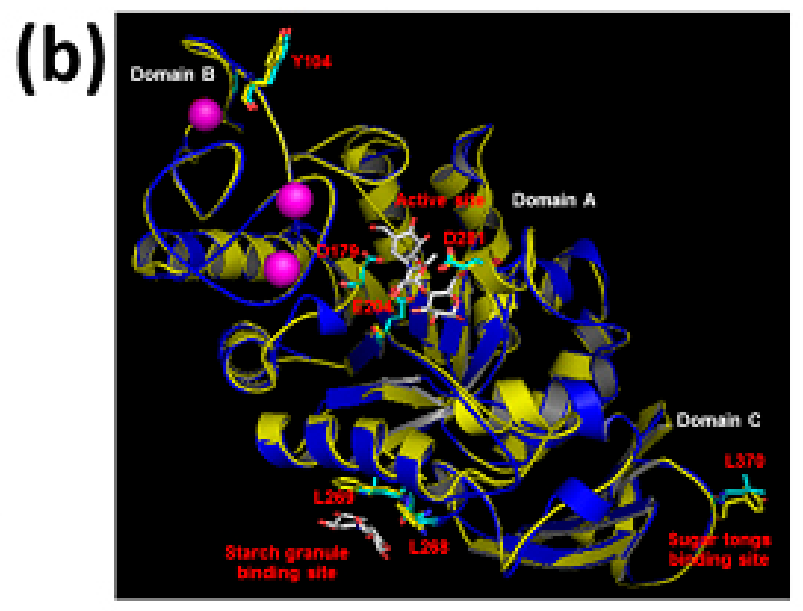

Figure 6. Three-dimensional structure modelling of DzAmy1. (a) Three-dimensional structure modelling of DzAmy1 that displays as a ribbon structure of $\alpha$-helices and $\beta$-strands composed of three domain (domain A (red), B (blue) and $\mathrm{C}$ (yellow)). The calcium ion represents as a green sphere. (b) Structural characterization of DzAmy1 using X-ray crystal structure of $2.8 \AA$ resolution barley $\alpha$-amylase AMY2 (1BG9) as a template (KADZIOLA et al., 1998). The superimposed structures of DzAmy1 (blue) and 1BG9 (yellow) are shown as ribbon structures. The acarbose bound at the catalytic cleft and starch-granule binding sites (disaccharide fragment) are shown as grey sticks. Important amino acids are highlighted as sticks (DzAmy1, blue; 1BG9, yellow). Calcium ions are represented as purple spheres.

Protein expression and purification of rDzAmyl

The cDNA encodes DzAmy1 conjugated pCold TF vector was expressed in BL-21 (DE3) competent cell. The colony PCR was used to verify the recombinant gene expression. The positive clone was induced using IPTG, and SDS-PAGE analysis revealed that DzAmy1 (43.7 $\mathrm{kDa}$ ) fused with $6 \mathrm{xHis}-\mathrm{TF}$ (trigger factor) ( $52 \mathrm{kDa})$ moved at the position of an expected size of approximately 96 $\mathrm{kDa}$ (Figure 7a). The rDzAmy1 purified by using talon column showed the expected single band at a molecular mass of approximately $96 \mathrm{kDa}$, and it was confirmed to have amylase activity by zymographic method (Figure
$7 \mathrm{~b})$. The activity assay indicated that rDzAmy1 had a strong ability to digest starch compared with the control (Figure 7c). rDzAmy 1 was active in the temperature of 4 , 37 and $50{ }^{\circ} \mathrm{C}$. It was highly active at 50 and $37{ }^{\circ} \mathrm{C}$ with activity more than $40 \%$ relative activity (Figure $7 \mathrm{~d}$ ). The rDzAmy1 also hydrolysed ethylidene-pNP-G7 substrate, which confirmed it to be an $\alpha$-type endo-amylase. 


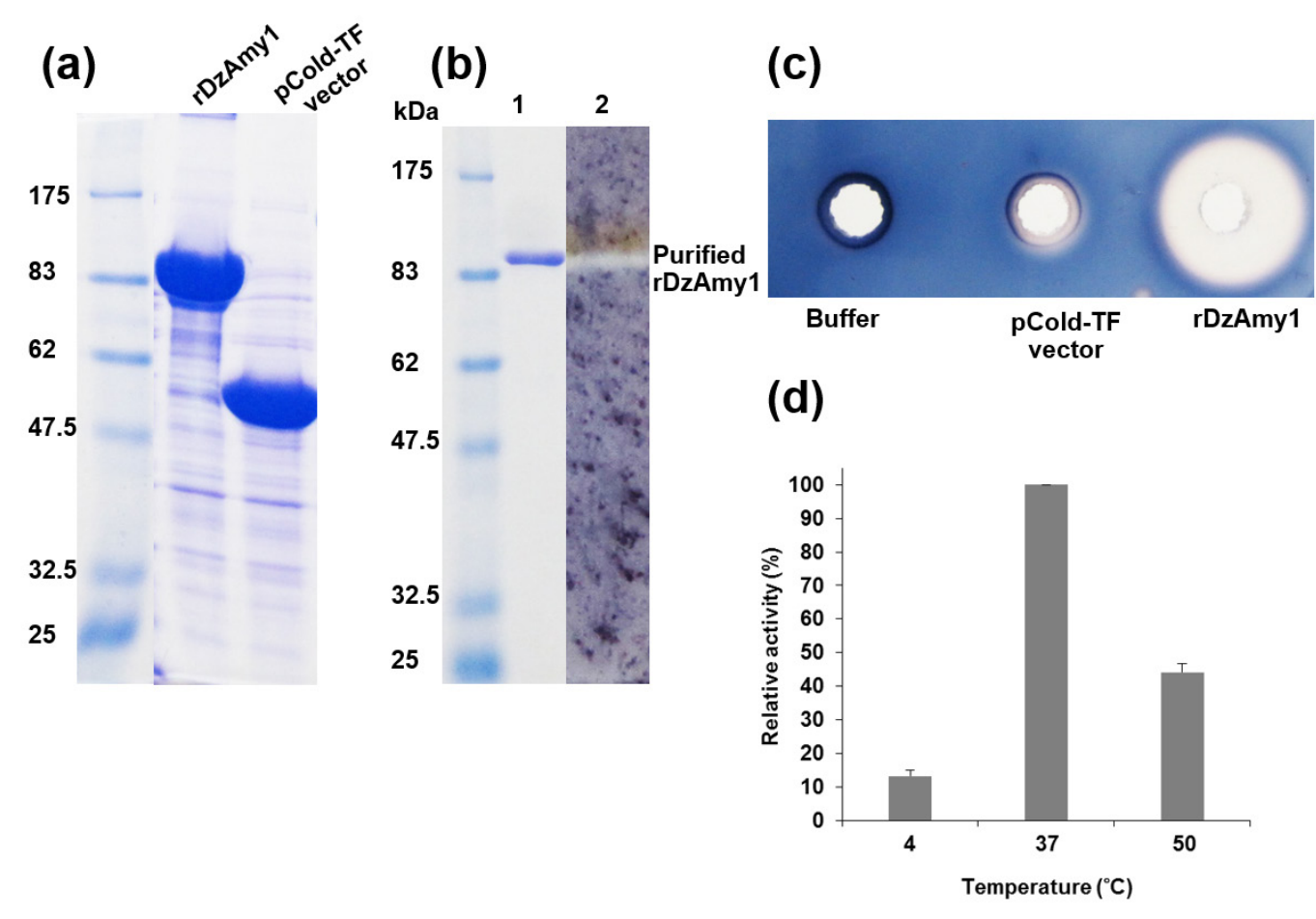

Figure 7. Expression and amylase activity analysis of recombinant DzAmy1. (a) SDS-PAGE analysis of DzAmy1 expression. (b) Purification of rDzAmy1 using affinity chromatography (lane 1) and analysis of amylase activity by the zymographic method (lane 2). (c) Amylase activity analysis on a starch agar plate. (d) The effect of temperature on amylase activity for rDzAmy 1 . The maximum activity at $37^{\circ} \mathrm{C}$ was $100 \%$ activity.

\section{Discussion}

The Mon Thong durian (Durio zibethinus Murr. $\mathrm{cv}$. Mon Thong) is the one of the most popular and seasonal tropical fruits in Southeast Asian countries such as Malaysia, Thailand, Indonesia, and the Philippine. It has unique taste and aroma and is dubbed as "king of fruits" (A AZIZ and MHD JALIL, 2019). Durian is rich in polyphenol, carbohydrates, phenolic acids, tannins and other bioactive molecules including proteins or peptides. The importance of this fruit is that it is composed of antioxidant nutrient compound, fatty acid and it has antiproliferative activity (HARUENKIT et al., 2010). However, the proteomic analysis of this fruit had not been reported yet. Hence, this work aimed to study about the proteomic analysis of durian, specifically focusing on amylase enzyme.

For the LC-MS/MS analysis of peptides of crude durian extract, we found that the proteins of this fruit were distinguished into 9 categories by the proteomic approach. The most of proteins were enzymes that participated in the biosynthesis pathways in ripening process. The enzymes involved in carbohydrate metabolism are thought to provide energy metabolites that are necessary for the ripening process. Heat shock proteins and chaperonins are important for the stabilization and folding of newly synthesized and existing proteins under stress conditions during fruit ripening (TOLEDO et al., 2012; NOGUEIRA et al., 2012). Among various enzymes involved in ripening process, glutathione reductase is an enzyme that reduces glutathione disulphide (GSSG) to the sulfhydryl form, namely glutathione (GSH) regarding in a unique smell of this fruit, and furthermore, GSH is also an important cellular antioxidant. Isoflavone reductase which catalyses the biosynthesis of isoflavonoid, is involved in the stress response, and its expression is increased during ripening (TOLEDO et al., 2012). Flavonoid glycosyltransferase is an enzyme involved in flavonoid biosynthesis that is predicted to be involved in producing yellow coloration during ripening. Flavonoid level is highest in ripe Mon Thong durian (HARUENKIT et al., 2010). Cell wall hydrolases are also important for cell-wall hydrolysis in fruit. Cellulase activity has been reported in ripening durian (KETSA et al., 1999). S-malonyltransferase (acyl-carrier protein) is an important enzyme for fatty-acid biosynthesis. Fatty acids were found in Mon Thong durian (HARUENKIT et al., 2010). 
In Mon Thong durian, the $\alpha$-amylase was a minor protein which was not able to identify using 2D-PAGE and LC-MS/MS. These results suggest that this enzyme show low expression but has dominant activity during the ripening process. In agreement with previous reports, $\alpha$-amylase was also not identified using 2D-PAGE in climacteric fruits including banana (TOLEDO et al., 2012), mango (ANDRADE et al., 2012), and papaya (NOGUEIRA et al., 2012). In peach (NMF cultivar), secreted $\alpha$-amylase has been identified as a minor protein that shows increased expression during ripening (PRINSI et al., 2011). However, $\alpha$-amylase genes have been reported that increased dramatically at both transcriptional and translational levels, which are in good agreement with the decrease in starch content and increase in total soluble sugars during banana ripening (XIAO et al., 2018). $\alpha$-Amylase plays a major role in starch degradation during banana ripening (BHUIYAN et al., 2020). We predicted that amylase in crude durian was a minor protein expressed in ripening state. The enzyme was corresponded to the minor protein band that was found in crude durian at the molecular mass of approximately $44 \mathrm{kDa}$ by the zymographic method for amylase activity. Therefore, we attempted to purify this minor $\alpha$-amylase by affinity chromatography in a single step using epoxy-activated sepharose 6B linked with $\beta$-cyclodextrin (KUMARI et al., 2010; TRIPATHI et al., 2007). As the result, purified enzyme showed the single band by SDS-PAGE with high amylase activity at approximately $44 \mathrm{kDa}$. This molecular mass corresponds to the size range $(38-53 \mathrm{kDa})$ of $\alpha$-amylases from other plant such as apple, Mung bean or red pitaya peel (KANWAL et al., 2004; NOMAN et al., 2006; SINGH et al., 2014; AMID et al., 2014). The enzymatic characterization of these enzymes was already determined. This DzAmy1 was highly active at $\mathrm{pH}$ values ranging from 6.0 to 8.0 , which is consistent with those of other $\alpha$-amylase previously reported (Table 3 ).

Table 3. Biochemical properties of some plant $\alpha$-amylases.

\begin{tabular}{|c|c|c|c|c|}
\hline Plant sources & $\begin{array}{l}\text { Molecular } \\
\text { weight } \\
(\mathrm{kDa})\end{array}$ & $\begin{array}{c}\text { Optimum } \mathrm{pH} \\
\text { (\% relative activity) }\end{array}$ & $\begin{array}{c}\text { Optimum } \\
\text { temperature } \\
(\% \text { relative activity) }\end{array}$ & References \\
\hline $\begin{array}{l}\text { Safflower } \\
\text { (Carthamus tinctorius L.) seeds }\end{array}$ & 35.0 & 6.0 & 55 & BEN ELARBI et al., 2009 \\
\hline $\begin{array}{l}\text { Apple } \\
\text { (Malus pumila) }\end{array}$ & 51.2 & 6.8 & 37 & KANWAL et al., 2004 \\
\hline Pachyrhizus erosus L. tuber & 40.0 & 7.3 & 37 & NOMAN et al., 2006 \\
\hline $\begin{array}{l}\text { Mung bean } \\
\text { (Vigna radiata) seeds }\end{array}$ & 46.0 & 5.6 & 65 & TRIPATHI et al., 2007 \\
\hline Soybean (Glycine max) seeds & 84.0 & 5.5 & 70 & KUMARI et al., 2010 \\
\hline $\begin{array}{l}\text { Wheat } \\
\text { (Triticum aestivum) seeds }\end{array}$ & 32.0 & 5.0 & 68 & SINGH et al., 2014 \\
\hline $\begin{array}{l}\text { Red pitaya } \\
\text { (Hylocereus polyrhizus) peel }\end{array}$ & 42.1 & 5.0 & 70 & AMID et al., 2014 \\
\hline Mon Thong durian (DzAmy1) & 44.0 & 7.0 & 50 & This study \\
\hline
\end{tabular}

Interestingly, DzAmy1 showed amylase activity on wide temperatures ranging from 30 to $80^{\circ} \mathrm{C}$, but the activity slightly decreased at 80 to $95^{\circ} \mathrm{C}$. It is consistent with the activity of red pitaya (Hylocereus polyrhizus) peel that the activity of DzAmy1 remained at high temperatures and its activity was higher than those of apple (Malus pumila) and Pachyrhizus erosus L. tuber (Table 3). This result shows that durian amylase is a thermostable enzyme, suggesting that structure, cofactors and enzyme-substrate complex might be involved in protecting it from heat denaturation (TRIPATHI et al., 2007). Mon Thong durian ripens at high humidity and high temperature during the summer in Thailand. Therefore, the high optimum temperature for its activity may be related to seasonal temperature.

The enzyme was stable and highly active over a wide range of $\mathrm{pH}$ values, from 6 to 10 . Generally, the stability of plant $\alpha$-amylases has been reported to show a narrow pH range (BRENA et al., 1996). DzAmy1 was stable over a wide range of temperatures, from 30 to $60^{\circ} \mathrm{C}$. However, DzAmy 1 activity was almost completely abolished by $5 \mathrm{mM}$ EDTA, which is consistent with observations of $\alpha$-amylases from mung bean and soy bean (KUMARI et al., 2010). The EDTA inhibition 
suggests that DzAmy1 is an $\alpha$-type amylase and a metalloenzyme. It was reported that the presence of $\mathrm{Ca}^{2+}$ improved the thermostability of $\alpha$-amylase from Bacillus licheniformis $\mathrm{NH} 1$ at $90^{\circ} \mathrm{C}$ (HMIDET et al., 2008). $\alpha$-Amylase is generally known to be more thermostable than $\beta$-amylase (MURALIKRISHNA et al., 2005), which is consistent with the properties of DzAmy1.

The sequences analysis of durian amylase indicated that this enzyme was classified in sub family 1 of plant $\alpha$-amylases. These enzymes of this group are important for the breakdown of extracellular starch in dicotyledonous seeds, the endosperm of cereal grains, and diseased tissues, and also during pollen tube germination (STANLEY et al., 2005). DzAmy1 seems to be an extracellular enzyme that possibly breaks down extracellular starch into sugar, creating sweetness during the ripening of Mon Thong durian.

The structural superposition of DzAmy1 revealed that the structure of the protein is mostly identical to structures of various $\alpha$-amylases previously reported, which have three domains, $\mathrm{A}, \mathrm{B}$ and $\mathrm{C}$, in a single polypeptide chain folded (KADZIOLA et al., 1994; ROBERT et al., 2003). The domains are predicted to be the catalytic $(\beta / \alpha)_{8}$ barrel (domain $\left.A\right)$, a potential functional diversity and stability domain (domain B) and a starch granule-binding domain (domain C) (SVENSSON et al., 1994). The modelling indicates that DzAmyl contains important one calcium ion as cofactor for folding, stability and activity (KADZIOLA et al., 1994). In principle, the calcium ion is assumed to interact with negatively charged amino acid residues, such as aspartic and glutamic acids, which maintain and stabilize the structure (ROGERS et al., 1985). Based on the proposed acid/base hydrolysis mechanism, Glu204 and Asp179 are suggested as the proton donor and the nucleophile, respectively (SVENSSON et al., 1994). The starch granule binding site in domain A may be critical for adsorption onto granular starch (KADZIOLA et al., 1998; ROBERT et al., 2005; SOGAARD et al., 1993) and the sugar tongs surface site which involved in enzymatic activity and particularly important for oligosaccharide and starch granules binding in domain $\mathrm{C}$ has been previously reported (Table 4) (BOZONNET et al., 2007). Two binding positions of oligosaccharide were Leu267 and Leu268 in the starch-granule binding surface site, and the sugar tongs surface site was Leu366 in DzAmy1 (Table 4).
The difficulty of purification of native DzAmy1 may limit further applications. However, since rDzAmyl was successfully produced using a cold shock expression plasmid with the trigger factor (TF) chaperone, the efficient production of the soluble protein may succeed. This system was used for the production of rDzAmy1, which is difficult to express in prokaryotic systems. So, further work must be done in order to improve it. However, as rD3Amyl was highly active at 37 and $50{ }^{\circ} \mathrm{C}$ as the native DzAmyl, it indicates that rDzAmy 1 could be a potential candidate for various applications in the future. 
Table 4. Structural analysis of plant $\alpha$-amylases.

\begin{tabular}{|c|c|c|c|c|c|c|}
\hline $\begin{array}{l}\text { Plant } \\
\text { sources }\end{array}$ & $\begin{array}{l}\text { Catalytic } \\
\text { site }\end{array}$ & $\begin{array}{l}\text { Calcium } \\
\text { binding site }\end{array}$ & $\begin{array}{l}\text { Starch granule } \\
\text { binding site }\end{array}$ & $\begin{array}{l}\text { Sugar } \\
\text { tongs }\end{array}$ & Analysis method & References \\
\hline $\begin{array}{l}\text { Barley } \\
\text { AMY1 }\end{array}$ & $\begin{array}{l}\text { Asp180, } \\
\text { Glu205, } \\
\text { Asp291 }\end{array}$ & $\begin{array}{l}\text { Asn92, } \\
\text { Asp139, } \\
\text { Ala142, } \\
\text { Asp149, } \\
\text { Gly184, } \\
\text { Glu109, } \\
\text { Thr112, } \\
\text { Asp114, } \\
\text { Asp118, } \\
\text { Asp128, } \\
\text { Asp143, } \\
\text { Phe144, } \\
\text { Ala147, } \\
\text { Asp149 }\end{array}$ & Trp278, Trp279 & Tyr380 & $\begin{array}{l}\text { Crystallographic } \\
\text { studies }\end{array}$ & ROBERT et al., 2003 \\
\hline $\begin{array}{l}\text { Barley } \\
\text { AMY2 }\end{array}$ & $\begin{array}{l}\text { Asp179, } \\
\text { Glu204, } \\
\text { Asp289 }\end{array}$ & $\begin{array}{c}\text { Asn91, } \\
\text { Asp138, } \\
\text { Ala141, } \\
\text { Asp148, } \\
\text { Gly183, } \\
\text { Glu108, } \\
\text { Thr111, } \\
\text { Asp113, } \\
\text { Asp117, } \\
\text { Asp127, } \\
\text { Asp142, } \\
\text { Phe143, } \\
\text { Ala146 }\end{array}$ & Trp276, Trp277 & Tyr378 & $\begin{array}{l}\text { Crystallographic } \\
\text { studies }\end{array}$ & KADZIOLA et al., 1994 \\
\hline Mung bean & $\begin{array}{l}\text { Asp182, } \\
\text { Glu207, } \\
\text { Asp290 }\end{array}$ & - & Val277, Lys278 & Met379 & Modelling studies & TRIPATHI et al., 2007 \\
\hline $\begin{array}{l}\text { Mon Thong } \\
\text { durian } \\
\text { (DzAmy3) }\end{array}$ & $\begin{array}{l}\text { Asp611, } \\
\text { Glu636, } \\
\text { Asp719 }\end{array}$ & $\begin{array}{c}\text { Asn529, } \\
\text { Ser570 } \\
\text { Asp573, } \\
\text { Asn580 } \\
\text { Gly615, } \\
\text { Gly546, } \\
\text { Asn550, } \\
\text { Asp560, } \\
\text { Asn574, } \\
\text { Phe575, } \\
\text { Ala577 }\end{array}$ & Trp706, Trp707 & Tyr807 & Modelling studies & $\begin{array}{l}\text { POSOONGNOEN et al., } \\
2015\end{array}$ \\
\hline $\begin{array}{l}\text { Mon Thong } \\
\text { durian } \\
\text { (DzAmy1) }\end{array}$ & $\begin{array}{l}\text { Asp179, } \\
\text { Glu204, } \\
\text { Asp280 }\end{array}$ & $\begin{array}{l}\text { Asn91, } \\
\text { Asp138, } \\
\text { Leu141, } \\
\text { Asp148, } \\
\text { Gly183, } \\
\text { Glu108, } \\
\text { Thr111, } \\
\text { Asp113, } \\
\text { Asp117, } \\
\text { Asp127, } \\
\text { Asp142, } \\
\text { Tyr143, } \\
\text { Ala146 }\end{array}$ & Leu267, Leu268 & Leu366 & Modelling studies & This study \\
\hline
\end{tabular}




\section{Acknowledgements}

We really appreciate (1) Professor Kenji Yamamoto, Research Institute for Bioresources and Biotechnology, Ishikawa Prefectural University, Nonoichi-shi, Ishikawa, Japan, and (2) Dr. Hiromichi Minami Research Institute for Bioresources and Biotechnology, Ishikawa Prefectural University, Nonoichi-shi, Ishikawa, Japan for their extreme contributions. This work was facilities and financially supported by (1) the Human Resource Development in Science Project (Science Achievement Scholarship of Thailand, SAST); (2) the Khon Kaen University (KKU) Research Fund, fiscal year 2009; (3) Nakhon Ratchasima Rajabhat University; and (4) Research and Academic Services, KKU; (5) the Research Institute for Bioresources and Biotechnology, Ishikawa Prefectural University, Japan.

\section{References}

AZIZ, N.A.; MHD JALIL, A.M. Bioactive compounds, nutritional value, and potential health benefits of indigenous durian (Durio zibethinus Murr.): a review. Foods, Basel, v.8, p.96, 2019.

AIYER, P.V. Amylases and their applications. African Journal of Biotechnology, Lagos, v.4, p.1525-1529. 2005.

AMID, M.; MANAP M.Y.A. Purification and characterization of a novel amylase enzyme from red pitaya (Hylocereus polyrhizus) peel. Food Chemistry, London, v.165, p.412-418, 2014.

ANDRADE, J.M.; TOLEDO, T.T.; NOGUEIRA, S.B.; CORDENUNSI, B.R.; LAJOLO, F.M.; OLIVEIRA DO NASCIMENTO, J.R. 2D-DIGE analysis of mango (Mangifera indica L.) fruit reveals major proteomic changes associated with ripening. Journal of Proteomics, Amsterdam, v.75, p.3331-3341, 2012.

ARNOLD, K.; BORDOLI, L.; KOPP, J.; SCHWEDE, T. The SWISS-MODEL workspace: a web-based environment for protein structure homology modelling. Bioinformatics, Oxford, v.22, p.195-201, 2006.
BAI-NGEW, S.; THERDTHAI, N.; DHAMVITHEE, P.; ZHOU, W. A study of the effect of the drying process on the composition and physicochemical properties of flours obtained from durian fruits of two ripening stages. International Journal of Food Science \& Technology, Oxford, v.49, p.230-237, 2014.

BEN ELARBI, M.; KHEMIRI, H.; JRIDI, T.; BEN HAMIDA, J. Purification and characterization of alpha amylase from safflower (Carthamus tinctorius L.) germinating seeds. Comptes Rendus Biologies, Paris, v.332, p.426-432, 2009.

BHUIYAN, F.R.; CAMPOS, N.A.; SWENNEN, R.; CARPENTIER, S. Characterizing fruit ripening in plantain and Cavendish bananas: A proteomics approach. Journal of Proteomics, Amsterdam, v.214, p.103632, 2020 .

BOZONNET, S.; JENSEN, M.T.; NIELSEN, M.M.; AGHAJARI, N.; JENSEN, M.H.; KRAMHOFT, B.; WILLEMOES, M.; TRANIER, S.; HASER, R.; SVENSSON, B. The 'pair of sugar tongs' site on the non-catalytic domain $\mathrm{C}$ of barley $\alpha$-amylase participates in substrate binding and activity. The FEBS Journal, Oxford, v.274, p.5055-5067, 2007.

BRENA, B.M.; PAZOS, C.; FRANCO-FRAGUAS, L.; BATISTA-VIERA, F. Chromatographic methods for amylases. Journal of Chromatography. B, Biomedical Sciences and Applications, Amsterdam, v.684, p.217237, 1996.

BUSH, D.S.; STICHER, L.; VAN HUYSTEE, R.; WAGNER, D.; JONES, R.L. The calcium requirement for stability and enzymatic activity of two isoforms of barley aleurone $\alpha$-amylase. Journal of Biological Chemistry, Baltimore, v.264, p.19392-19398, 1989.

CHAROENKIATKUL, S.; THIYAJAI, P.; JUDPRASONG, K. Nutrients and bioactive compounds in popular and indigenous durian (Durio zibethinus Murr.). Food Chemistry, London, v.193, p.181-186, 2016. 
D’AMBROSIO, C.; ARENA, S.; ROCCO, M.; VERRILLO, F.; NOVI, G.; VISCOSI, V.; MARRA, M.; SCALONI, A. Proteomic analysis of apricot fruit during ripening. Journal of Proteomics, Amsterdam, v.78, p.39-57, 2013.

DREHER, M.L. Whole fruits and fruit fiber emerging health effects. Nutrients, Basel, v.10, p.1833, 2018.

HARUENKIT, R.; POOVARODOM, S.; VEARASILP, S.; NAMIESNIK, J.; SLIWKA-KASZYNSKA, M.; PARK, YS.; HEO, BG.; CHO, JY.; JANG, HG.; GORINSTEIN, $\mathrm{S}$. Comparison of bioactive compounds, antioxidant and antioxidant and antiproliferative activities of Mon Thong durian during ripening. Food Chemistry, London, v.118, p.540-547, 2010 .

HARUENKIT, R.; POOVARODOM, S.; LEONTOWICZ, H.; LEONTOWICZ, M.; SAJEWICZ, M.; KOWALSKA, T.; DELGADO-LICON, E.; ROCHA-GUZMÁN, N.E.; GALLEGOS-INFANTE, J.A.; TRAKHTENBERG, S.; GORINSTEIN, S. Comparative study of health properties and nutritional value of durian, mangosteen, and snake fruit: experiments in vitro and in vivo. Journal of Agricultural and Food Chemistry, Washington, v.55, p.5842-5849, 2007.

HMIDET, N.; BAYOUDH, A.; BERRIN, J.G.; KANOUN, S.; JUGE, N.; NASRI, M. Purification and biochemical characterization of a novel $\alpha$-amylase from Bacillus licheniformis NH1, p. Cloning, nucleotide sequence and expression of amyN gene in Escherichia coli. Process Biochemistry, London, v.43, p.499-510, 2008.

JAIN, N.; DHAWAN, K.; MALHOTRA, S.; SINGH, R. Biochemistry of fruit ripening of Guava (Psidium guajava L.): Composition and enzymatic changes. Plant Foods for Human Nutrition, Dordrecht, v.58, p.309-315, 2003.

JOSEPH, S.V.; EDIRISINGHE, I.; BURTON-FREEMAN, B.M. Fruit polyphenols: a review of anti-inflammatory effects in humans. Critical Reviews in Food Science and Nutrition, Boca Raton, v.56, p.419-444, 2016.

KADZIOLA, A.; ABE, J.; SVENSSON, B.; HASER, R. Crystal and molecular structure of barley $\alpha$-amylase. Journal of Molecular Biology, Amsterdam, v.239, p.104121, 1994.
KADZIOLA, A.; SOGAARD, M.; SVENSSON, B.; HASER, R. Molecular structure of a barley $\alpha$-amylase inhibitor complex: implications for starch binding and catalysis. Journal of Molecular Biology, Amsterdam, v.278, p. 205-217, 1998.

KANWAL, B.; ZIA, M.A.; YASIN, M.; RAHMAN, K.; SHEIKH, M. Purification and characterization of $\alpha$-amylase from apple (Malus pumila). International Journal of Agriculture and Biology, Faisalabad, v.6, p.233-236. 2004.

KETSA, S.; DAENGKANIT, T. Physiological changes during postharvest ripening of durian fruit (Durio zibethinus Murray). Journal of Horticultural Science and Biotechnology, Ashford, v.73, p.575-577, 1998.

KETSA, S.; DAENGKANIT, T. Firmness and activities of polygalacturonase, pectinesterase, beta-galactosidase and cellulase in ripening durian harvested at different stages of maturity. Scientia Horticulturae, Amsterdam, v.80, p.181-188, 1999.

KIEFER, F.; ARNOLD, K.; KUNZLI, M.; BORDOLI, L.; SCHWEDE, T. The SWISS-MODEL repository and associated resources. Nucleic Acids Research, London, v.37, p.D387-D392, 2009.

KUMARI, A.; SINGH, V.K.; FITTER, J.; POLEN, T.; KAYASTHA, A.M. $\alpha$-Amylase from germinating soybean (Glycine $\max$ ) seeds-purification, characterization and sequential similarity of conserved and catalytic amino acid residues. Phytochemistry, Oxford, v.71, p.1657-1666, 2010.

LAEMMLI, U.K. Cleavage of structural proteins during the assembly of the head of bacteriophage T4. Nature, London, v.227, p.680-685, 1970.

LARKIN, M.A.; BLACKSHIELDS, G.; BROWN, N.P.; CHENNA, R.; MCGETTIGAN, P.A.; MCWILLIAM, H.; VALENTIN, F.; WALLACE, I.M.; WILM, A.; LOPEZ, R.; THOMPSON, J.D.; GIBSON, T.J.; HIGGINS, D.G. Clustal W and Clustal X version 2.0. Bioinformatics, Oxford, v.23, p.2947-2948, 2007. 
MURALIKRISHNA, G.; NIRMALA, M. Cereal $\alpha$-amylases-An overview. Carbohydrate Polymers, London, v.60, p.163-173, 2005.

NIELSEN, H.; ENGELBRECHT, J.; BRUNAK, S.; VON HEIJNE, G. Identification of prokaryotic and eukaryotic signal peptides and prediction of their cleavage sites. Protein Engineering, Oxford, v.10, p.1-6, 1997.

NOGUEIRA, S.B.; LABATE, C.A.; GOZZO, F.C.; PILAU, E.J.; LAJOLO, F.M.; OLIVEIRA DO NASCIMENTO, J.R. Proteomic analysis of papaya fruit ripening using 2DE-DIGE. Journal of Proteomics, Amsterdam, v.75, p.1428-1439, 2012.

NOMAN, A.S.M.; HOQUE, M.A.; SEN, P.K.; KARIM, M.R. Purification and some properties of $\alpha$-amylase from post-harvest Pachyrhizus erosus L. tuber. Food Chemistry, London, v.99, p.444-449, 2006.

P O S O O N G N O E , S .; U B O N B A L, R .; THAMMASIRIRAK, S.; DADUANG, J.; MINAMI, H.; YAMAMOTO, K.; DADUANG, S. $\alpha$-Amylase from Mon Thong durian (Durio zibethinus Murr. cv. Mon Thong)nucleotide sequence analysis, cloning and expression. Plant Biotechnology, Tokyo, v.32, p.1-10, 2015.

PRINSI, B.; NEGRI, A.S.; FEDELI, C.; MORGUTTI, S.; NEGRINI, N.; COCUCCI, M.; ESPEN, L. A proteomic comparative analysis of the mesocarp of two cultivars with different flesh firmness at two ripening stages. Phytochemistry, Oxford, v.72, p.1251-1262, 2011.

ROBERT, X.; HASER, R.; GOTTSCHALK, T.E.; RATAJCZAK, F.; DRIGUEZ, H.; SVENSSON, B.; AGHAJARI N. The structure of barley $\alpha$-amylase isozyme 1 reveals a novel role of domain $\mathrm{C}$ in substrate recognition and binding: a pair of sugar tongs. Structure, London, v.11, p.973-984, 2003.

ROBERT, X.; HASER, R.; MORI, H.; SVENSSON, B.; AGHAJARI, N. Oligosaccharide binding to barley $\alpha$-amylase 1. Journal of Biological Chemistry, Baltimore, v.280, p.32968-32978, 2005.
ROGERS, J.C. Two barley alpha-amylase gene families are regulated differently in aleurone cells. Journal of Biological Chemistry, Baltimore, v.260, p.3731-3738, 1985.

RONDANELLI, M.; FALIVA, M.A.; MICCONO, A.; NASO, M.; NICHETTI, M.; RIVA, A.; GUERRIERO, F.; DE GREGORI, M.; PERONI, G.; PERNA, S. Food pyramid for subjects with chronic pain: foods and dietary constituents as anti-inflammatory and antioxidant agents. Nutrition Research Reviews, Cambridge, v.31, p.131151,2018

RUNGSA, P.; INCAMNOI, P.; SUKPRASERT, S.; UAWONGGUL, N.; KLAYNONGSRUANG, S.; DADUANG, J.; PATRAMANON, R.; ROYTRAKUL, S.; DADUANG, S. Comparative proteomic analysis of two wasps venom, Vespa tropica and Vespa affinis. Toxicon, Oxford, v.119, p.159-167, 2016.

SAITOU, N.; NEI, M. The neighbour-joining method: a new method for reconstructing phylogenetic trees. Molecular Biology and Evolution, Oxford, v.4, p.406$425,1987$.

SCHWEDE, T.; KOPP, J.; GUEX, N.; PEITSCH, M.C. SWISS-MODEL: An automated protein homologymodelling server. Nucleic Acids Research, London, v.31, p.3381-3385, 2003.

SINDHU, R.; BINOD, P.; MADHAVAN, A.; BEEVI, U.S.; MATHEW, A.K.; ABRAHAM, A.; PANDEY, A.; KUMAR, V. Molecular improvements in microbial $\alpha$-amylases for enhanced stability and catalytic efficiency. Bioresource Technology, Barking, v.245, p.1740-1748, 2017.

SINGH, K.; KAYASTHA, A.M. Alpha-amylase from wheat (Triticum aestivum) seeds: its purification, biochemical attributes and active site studies. Food Chemistry, London, v.162, p.1-9, 2014.

SOGAARD, M.; KADZIOLA, A.; HASER, R.; SVENSSON, B. Site-directed mutagenesis of histidine 93, aspartic acid 180, glutamic acid 205, histidine 290, and aspartic acid 291 at the active site and tryptophan 279 at the raw starch binding site in barley $\alpha$-amylase 1. Journal of Biological Chemistry, Baltimore, v.268, p.22480-22484, 1993. 
SOUZA, P.; PEROLA, O. Application of microbial $\alpha$-amylase in industry - a review. Brazilian Journal of Microbiology, Rio de Janeiro, v.41, p.850-861, 2010.

STANLEY, D.; FARNDEN, K.J.F.; MACRAE, E.A. Plant $\alpha$-amylases: functions and roles in carbohydrate metabolism. Biologia (Bratisl), Bratislava, v.60, p.65-71, 2005.

SUKPRASERT, S.; RUNGSA, P.; UAWONGGUL, N.; INCAMNOI, P.; THAMMASIRIRAK, S.; DADUANG, J.; DADUANG, S. Purification and structural characterization of phospholipase A1 (Vespapase, Ves a 1) from Thai banded tiger wasp (Vespa affinis) venom. Toxicon, Oxford, v.61, p.151-164, 2013.

SVENSSON, B. Protein engineering in the $\alpha$-amylase family: catalytic mechanism, substrate specificity and stability. Plant Molecular Biology, Dordrecht, v.25, p.141-157, 1994.

TAMURA, K.; PETERSON, D.; PETERSON, N.; STECHER, G.; NEI, M.; KUMAR, S. MEGA5: molecular evolutionary genetics analysis using maximum likelihood, evolutionary distance, and maximum parsimony methods. Molecular Biology and Evolution, Oxford, v.28, p.27312739, 2011.
TOLEDO, T.T.; NOGUEIRA, S.B.; CORDENUNSI, B.R.; GOZZO, F.C.; PILAU, E.J.; LAJOLO, F.M.; DO NASCIMENTO, J.R.O. Proteomic analysis of banana fruit reveals proteins that are differentially accumulated during ripening. Postharvest Biology and Technology, Amsterdam, v.70, p.51-58, 2012.

TRIPATHI, P.; LO LEGGIO, L.; MANSFELD, J.; ULBRICH-HOFMANN, R.; KAYASTHA, A.M. $\alpha$-Amylase from mung beans (Vigna radiata)-correlation of biochemical properties and tertiary structure by homology modelling. Phytochemistry, Oxford, v.68, p.1623-1631, 2007.

UBONBAL, R.; PORSOONGNOEN, S.; DADUANG, J.; KLAYNONGSRUANG, S.; DADUANG, S. Purification and characterization of two isoforms of native $\alpha$ amylase from Ok-Rong mango (Mangifera indica Linn. cv. OkRong). Turkish Journal of Biochemistry, Ankara, v.42, p.624-632, 2017.

XIAO, Y.Y,; KUANG, J.F.; QI, X.N.; YE, Y.J.; WU, Z.X.; CHEN, J.Y.; LU, W.J. A comprehensive investigation of starch degradation process and identification of a transcriptional activator MabHLH6 during banana fruit ripening. Plant Biotechnology Journal, Oxford, v.16, p.151-164, 2018. 